\title{
PEMANFAATAN JUDUL-JUDUL LAGU UNTUK MENINGKATKAN KETERAMPILAN MENULIS PUISI PADA SISWA KELAS VII MTSN 3 BANJARMASIN
}

\author{
Ngatiyem \\ MTsN 3 Banjarmasin \\ Jl. Bakti No. 4 RT.23/RW.04, Pemurus Dalam, \\ Banjarmasin Selatan, Kalimantan Selatan \\ email: Ngatiyem.fitri@gmail.com
}

\begin{abstract}
ABSTRAK
Keterampilan menulis Puisi pada siswa kelas VII MTsN 3 Banjarmasin masih rendah. Hal ini merupakan dasar pemikiran yang melandasi penggunaan media dalam pembelajaran menulis sebuah Puisi. Tujuan penelitian ini adalah untuk (1) Mendeskripsikan keterampilan siswa kelas VII MTsN 3 Banjarmasin terhadap pembelajaran menulis Puisi melalui metode penggunan judul-judul lagu. (2) Memaparkan aktivitas siswa kelas VII MTsN 3 Banjarmasin terhadap pembelajaran menulis Puisi melalui metode penggunaan judul-judul lagu. (3) Mendeskripsikan respons siswa kelas VII MTsN 3 Banjarmasin dalam menulis uisi melalui metode Penggunaan Judul-Judul Lagu

Metode penelitian ini adalah penelitian tindakan kelas, yaitu prosedur penelitian yang menghasilkan data deskriftif berupa kata-kata tertulis atau lisan dari orang-orang dan perilaku yang dapat diamati pelaksanaan tindakan melalui dua siklus. Setiap siklus terdiri dari dua kali pertemuan dengan tahapan perencanaan, pelaksanan tindakan, pengamatan, dan refleksi. Objek penelitian adalah siswa kelas VII MTsN 3 Banjarmasin yang berjumlah 32 orang siswa. Hasil penelitian menunjukan bahwa Pengunaan Metode pemanfaatan Judul-Judul lagu dapat meningkatkan keterampilan siswa menulis. Indikator keberhasilan ini terlihat dari adanya peningkatan hasil belajar siswa, peningkatan aktivitas guru dan siswa, serta respon siswa yang cukup tinggi.

Hasil penelitian ini adalah: (1) hasil belajar siswa rata-rata pada siklus I pertemuan pertama dan kedua masih rendah. Pada siklus II pertemuan ketiga dan keempat mengalami peningkatan, pada pertemuan ketiga dengan rata-rata pretest 72,18 dengan ketuntasan klasikal $84 \%$, dan pada pertemuan ke empat rata-rata postest 79,06 dengan ketuntasan klasikal 100\%. (2) nilai aktivitas guru pada siklus I ke Siklus II terjadi peningkatan dengan nilai rata rata 4 dalam pembelajaran menulis Puisi dengan kategori pencapaian nilai amat baik. Demikian juga aktivitas murid juga mengalami peningkatan. Dalam hal ini aktivitas murid pada pembelajaran menulis Puisi semakin meningkat pada setiap pertemuan (3) Respons murid dalam pembelajaran menulis Puisi menggunakan metode pemanfaatan judul-judul lagu cukup baik.dengan total persentasi hampir $100 \%$.
\end{abstract}

Kata kunci: lagu, keterampilan menulis, puisi

\section{PENDAHULUAN}

Keterampilan berbahasa (language arts, language skills) dalam kurikulum di sekolah biasanya mencakup empat segi/komponen, yaitu keterampilan menyimak (listening skills), keterampilan berbicara (speaking skills), keterampilan membaca (reading skills), keterampilan menulis (writing skills). Setiap keterampilan itu erat sekali hubungannya dengan tiga keterampilan lainnya dengan cara 
yang beraneka ragam. Dalam memperoleh keterampilan berbahasa, biasanya melalui suatu hubungan urutan yang teratur: mula-mula pada masa kecil kita belajar menyimak bahasa kemudian berbicara, sesudah itu kita belajar membaca dan menulis. Menyimak dan berbicara kita pelajari sebelum memasuki masa sekolah. Keempat keterampilan tersebut pada dasarnya merupakan suatu kasatuan, merupakan catur tunggal. (Tarigan, 1982:1)

Keterampilan menulis merupakan suatu keterampilan berbahasa yang dipergunakan untuk berkomunikasi secara tidak langsung, tidak secara tatap muka dengan orang lain. Keterampilan menulis juga merupakan suatu kegiatan yang produktif dan ekspresif. Dalam kegiatan menulis ini maka sang penulis haruslah trampil memanfaatkan grafologi, struktur bahasa, dan kosa kata. Keterampilan menulis ini tidak akan datang secara otomatis, melainkan harus melalui latihan dan praktik yang banyak dan teratur. (Tarigan, 1982:3). Dalam kehidupan modern ini jelas bahwa keterampilan menulis sangat dibutuhkan.

Pembelajaran menulis sekarang ini belum maksimal berdasarkan observasi yang terdapat dilapangan, karena peserta didik belum terbiasa melakukan kegiatan menulis atau masih menggunakan cara biasa, selain itu juga faktor waktu yang sangat terbatas. Peserta didik sekarang banyak disuguhi dengan berbagai macam jenis buku teks pelalajan, sehingga jarang sekali umtuk menulis karena dalam buku pelajaran tersebut sudah lengkap tentang apa yang dipelajarkan, itulah sebagian sebab mengapa menulis sekarang ini belum maksimal. Oleh sebab itu peneliti tertarik untuk mengangkat permasalahan ini ke dalam sebuah penelitian dengan model pembelajaran menggunakan media kumpulan kata kata yang bermakna dalam yang terdapat pada judul-judul lagu. Penelitian yang dilakukan oleh peneliti ini berjudul "Meningkatkan Keterampilan Menulis Puisi Dengan Menggunakan Metode Pemanfaatan Judul-Judul Lagu Pada Siswa Kelas VII MTsN 3 Banjarmasin”. Tujuan penelitian adalah untuk: 1. Mendeskripsikan keefektifan pemanfaatan judul-judul lagu dalam pembelajaran menulis puisi pada siswa kelas VII MTsN 3 Banjarmasin. 2. Mendeskripsikan tentang hasil pembelajaran menulis puisi dengan menggunakan judul judul lagu pada siswa kelas VII MTsN 3 Banjarmasin. 3. Mendeskripsikan respons siswa kelas VII MTsN 3 Banjarmasin dalam menulis puisi melalui pemanfaatan judul-judul lagu.

\section{METODE}

Penelitian tindakan kelas ini dilaksanakan di MTsN 3 Banjarmasin yang terletak di jalan Mahligai Kabupaten Banjar. Rencana penelitian yang digunakan adalah Penelitian tindakan kelas (PTK). Penelitian tindakan kelas (PTK) merupakan salah satu pendekatan dalam penelitian yang 
berbasis dalam kelas atau sekolah yang bertujuan untuk memecahakan berbagai permasalahan yang digunakan dalam rangka peningkatan kualitas pendidikan. Penelitian tindakan kelas (classroom Action research $C A R$ ) ditulis oleh Arikunto. Dengan pengalaman nya yang demikian luas di bidang penelitian tindakan makna dan hakikat PTK di paparkan secara rinci dengan gaya kelas (PTK) sebagai bagian dari penelitian tindakan (action research) yang bertujuan memperbaiki mutu praktik pembelajaran di kelas. Faktor yang diteliti

\section{a. Faktor Murid}

Penelitian ini bertujuan untuk mengetahui sejauh mana keterampilan siswa kelas VII MTsN 3 Banjarmasin dalam kegiatan menulis terutama dalam menulis puisi melalui pemanfaatan judul judul lagu, sebagaimana diketahui masih terdapat kekurangan bagi siswa dalam keterampilan menulis tersebut.

b. Faktor Guru

Untuk meningkatkan sejauh mana keterampilan menulis puisi khususnya pada siswa kelas VII MTsN 3 Banjarmasin, Guru berperan sangat penting demi terlaksananya proses belajar-mengajar. Misalnya dalam kegiatan mengelola kelas pada saat kegiatan pembelajaran berlangsung, menyiapkan semua materi yang akan disampaikan, serta menyiapakan strategi dan model pembelajaran yang tepat guna terciptanya suasana yang aman, nyaman, tenang, serta kondusif.

Teknik Pengumpulan Data yang digunakan dalam penelitian ini adalah: Observasi, Wawancara, tes.

\section{HASIL DAN PEMBAHASAN}

\section{Permasalahan dalam Pembelajaran}

Permasalahan yang menjadi kendala dalam pembelajaran di kelas VII MTsN 3 Banjarmasin dapat dilihat dari dua sudut pandang, yaitu: (1) dilihat dari sisi siswa, kurangnya keterampilan menulis, terutama dalam menulis sebuah teks berita, motivasi dan konsentrasi belajar kurang, serta kesan yang tampak pada siswa bahwa pelajaran teks berita yang mereka pelajari seakan-akan kurang bermanfaat dalam kehidupannya sehari-hari, (2) dilihat dari sisi guru, masih terdapat banyak kekurangan terutama dalam hal kesiapan mengajar, guru lebih cendrung mendominasi kegiatan pembelajaran, kurang melibatkan aktivitas siswa dalam proses pembelajaran, kurang memperdayakan potensi peserta didik, motivasi dan gairah belajar siswa masih kurang terutama keterampilan menulis seperti dalam hal menulis sebuah Puisi. 
Nilai Yang Diperoleh Murid Pada Proses Pembelajaran Siklus I

(Pertemuan 1)

\begin{tabular}{|c|c|c|c|c|c|}
\hline \multirow[t]{4}{*}{ No } & \multirow{4}{*}{ Nama Siswa } & \multicolumn{4}{|l|}{ Siklus I } \\
\hline & & \multirow{2}{*}{\multicolumn{4}{|c|}{ Pertemuan 1}} \\
\hline & & & & & \\
\hline & & Pre test & Ketuntasan & Post test & Ketuntasan \\
\hline 1 & AHMAD ARDANA & 60 & TT & 70 & $\mathrm{~T}$ \\
\hline 2 & AHMAD BAIDAWI & 60 & TT & 70 & $\mathrm{~T}$ \\
\hline 3 & AHMAD FADILAH & 60 & TT & 70 & $\mathrm{~T}$ \\
\hline 4 & AHMAD FAUZAN & 60 & TT & 70 & $\mathrm{~T}$ \\
\hline 5 & AHMAD MUZADI & 60 & TT & 70 & $\mathrm{~T}$ \\
\hline 6 & AKHMAD FAHMI & 50 & TT & 60 & TT \\
\hline 7 & DEA SHAFIRA ADISTI & 50 & TT & 60 & TT \\
\hline 8 & DHEA SAPUTRI & 50 & TT & 60 & TT \\
\hline 9 & DINA RIZKA & 50 & TT & 60 & TT \\
\hline 10 & DINA SAFIRA & 50 & TT & 60 & TT \\
\hline 11 & HABIBAH SALWA & 60 & TT & 60 & TT \\
\hline 12 & $\begin{array}{l}\text { M. RISWANA } \\
\text { ANUGERAH }\end{array}$ & 60 & TT & 60 & TT \\
\hline 13 & M. RIZWAN FAZERI & 60 & TT & 60 & TT \\
\hline 14 & M. NOR ANNAS JAMIL & 60 & TT & 60 & TT \\
\hline 15 & MARSA ALIFIA & 60 & TT & 60 & TT \\
\hline 16 & $\begin{array}{l}\text { MUHAMMAD ALI } \\
\text { MUSTOFA }\end{array}$ & 60 & TT & 60 & TT \\
\hline 17 & MUHAMMAD FAHLEVI & 60 & TT & 60 & TT \\
\hline 18 & MUHAMMAD LUTHFI & 60 & TT & 60 & TT \\
\hline
\end{tabular}


Vol.3 No.2, 1 Oktober 2018

\begin{tabular}{|l|l|l|l|l|l|}
\hline 19 & $\begin{array}{l}\text { MUHAMMAD RAIHAN } \\
\text { RIDHA }\end{array}$ & 60 & TT & 60 & TT \\
\hline 20 & $\begin{array}{l}\text { MUHAMMAD RIZKI } \\
\text { ANANDA }\end{array}$ & 60 & TT & 60 & TT \\
\hline 21 & MUHAMMAD SYAFI'E & 50 & TT & 80 & T \\
\hline 22 & MUNAWARAH & 50 & TT & 80 & T \\
\hline 23 & MUTIA WAHIDAH & 50 & TT & 80 & T \\
\hline 24 & MUTIARA QALBINA & 50 & TT & 80 & T \\
\hline 25 & NAIMATUL HUDA & 50 & TT & 80 & T \\
\hline 26 & NIA RAMADHANI & 70 & T & 80 & T \\
\hline 27 & NIDA SYAFIRA & 70 & T & 80 & T \\
\hline 28 & $\begin{array}{l}\text { NOOR HAYA AGNA } \\
\text { NUZILLA }\end{array}$ & 70 & T & 80 & T \\
\hline 29 & NOOR FINA RAHMAH & 70 & T & 80 & T \\
\hline 30 & NURHIDAYAH & 70 & T & 80 & T \\
\hline 31 & RAUDATUL KHATIMAH & 70 & T & 80 & T \\
\hline 32 & RIZQA MAULIDA & 70 & T & 80 & T \\
\hline
\end{tabular}

Keterangan:

85-100

$75-85$

$65-75$

$55-65$
: Sangat Baik

: Baik

: Cukup

: Kurang
$\mathrm{T}=$ Tuntas

$\mathrm{TT}=$ Tidak Tuntas

Ketuntasan Individu dan Klasikal yang Diperoleh Dari Hasil Pre Test Dan Post Test Siklus I

\section{Hasil belajar siklus I}

\section{Pertemuan ke 1}

\begin{tabular}{|l|l|l|l|l|}
\hline Tes & Tuntas & Tidak tuntas & $\begin{array}{l}\text { Jumlah } \\
\text { murid }\end{array}$ & $\begin{array}{l}\text { \% } \\
\text { Tuntas }\end{array}$ \\
\hline Pre Test & $\mathbf{1 2}$ & 20 & $\mathbf{3 2}$ & $\mathbf{3 7} \%$ \\
\hline Post Test & $\mathbf{1 7}$ & $\mathbf{1 5}$ & $\mathbf{3 2}$ & $\mathbf{5 3 \%}$ \\
\hline
\end{tabular}


(sumber data pre test dan post test siklus I)

Dari tabel di atas dapat dibuat grafik sebagai berikut:

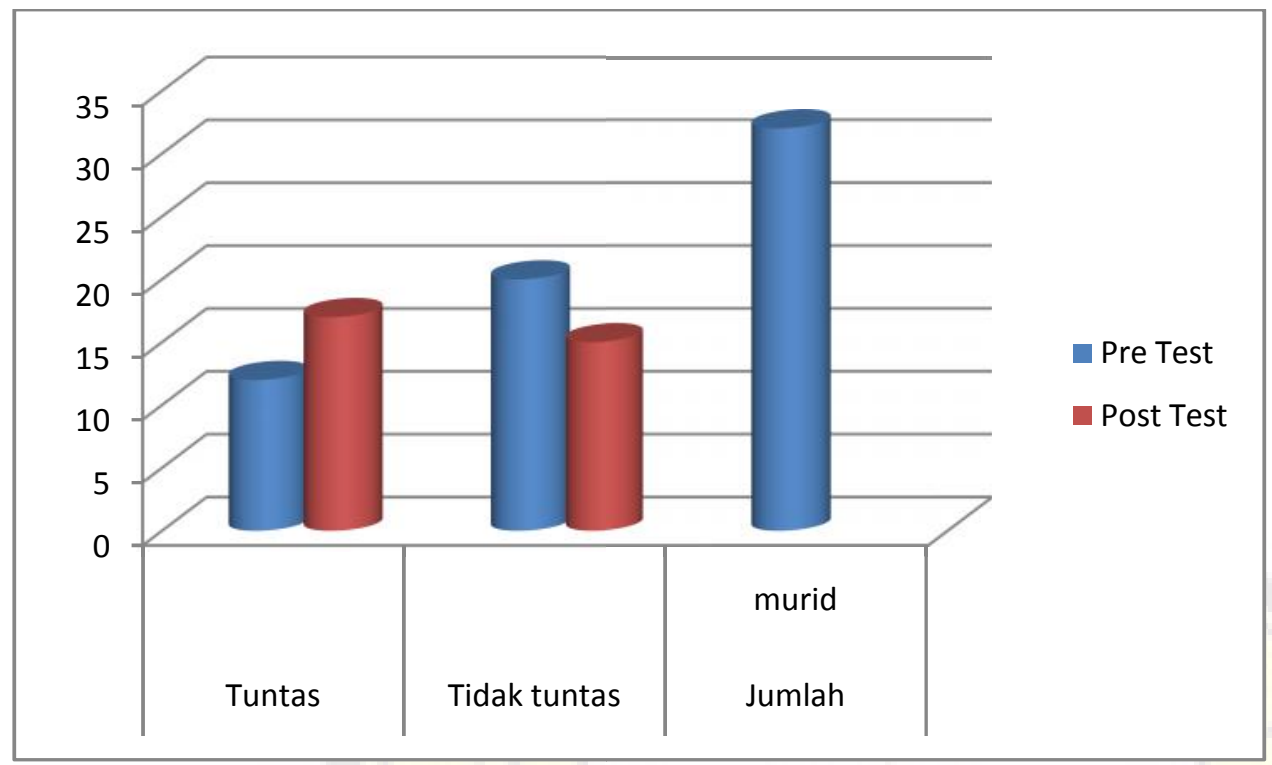

Berdasarkan Tabel 4.3 Ketuntasan Secara Individual dan Klasikal Melalui Pretest Belum Tuntas, Karena Hanya 12 Orang yang Tuntas Belajar dengan Nilai Rata Rata Pre Test Adalah 59,06 Sedangkan Nilairata Rata Post Test Adalah 69,06, Dengan Ketuntasan Klasikal Untuk Pretest Adalah 37 \%, Dan Post Test Adalah 53 \% Pada Pertemuan 1.

\section{Ketuntasan Individu Dan Klasikal Yang Diperoleh Dari Hasil PreTest Dan Post Test Siklus}

\begin{tabular}{|l|l|l|l|l|}
\hline \multicolumn{5}{|l|}{ Hasil belajar siklus I } \\
\hline Pertemuan ke 2 & Tuntas & Tidak tuntas & $\begin{array}{l}\text { Jumlah } \\
\text { Murid }\end{array}$ & $\begin{array}{l}\% \\
\text { Tuntas }\end{array}$ \\
\hline Tes & 17 & 15 & 32 & $53 \%$ \\
\hline Pre Test & 22 & 10 & 32 & $69 \%$ \\
\hline Post Test & & & & \\
\hline
\end{tabular}

(sumber data pre test dan post test siklus I) 
Dari tabel di atas dapat dibuat grafik sebagai berikut:

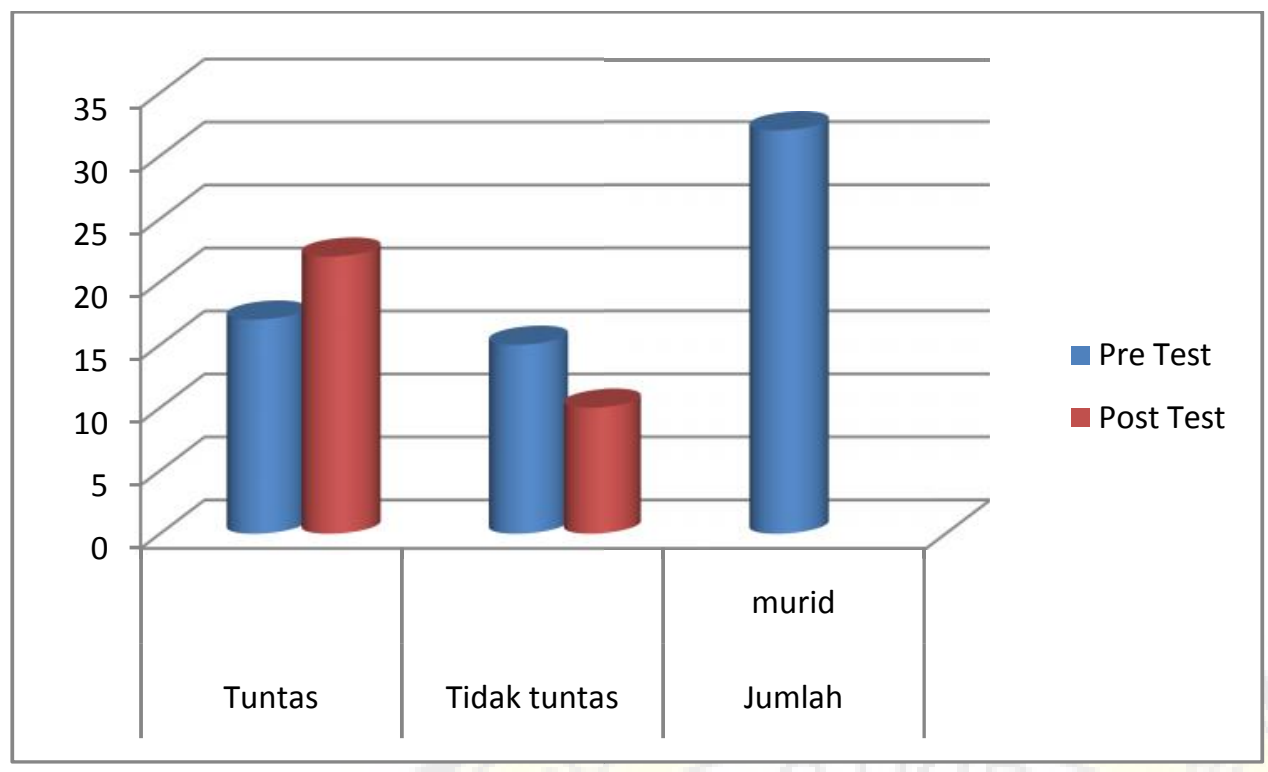

Berdasarkan tabel 4 pada pertemuan 2 ketuntasan secara indinidual dan klasikal mwlalui pretest belum tuntas karena hanya 17 Orang yang tuntas belajar dengan nilai rata rata pretest afalah 65,31 dan pos test adalah 70. 62 dan ketuntasan klasikal untuk pretest adalah $53 \%$ dan post test $69 \%$.

\section{Hasil Observasi Aktivitas Guru Dalam Mengelola Pembelajaran}

\begin{tabular}{|c|c|c|c|c|c|c|}
\hline \multirow[t]{2}{*}{ No } & \multirow[t]{2}{*}{ Aspek yang diamati } & \multicolumn{2}{|c|}{ Dilakukan } & \multicolumn{2}{|c|}{ Penilaian } & \multirow[t]{2}{*}{ Kategori } \\
\hline & & P1 & $\mathrm{P} 2$ & $\mathrm{X}$ & $\mathrm{Y}$ & \\
\hline 1 & $\begin{array}{l}\text { Persiapan } \\
\text { a. Menyiapkan perangkat pembelajaran } \\
\text { b. Menyiapkan media pembelajaran }\end{array}$ & $\begin{array}{l}3 \\
3\end{array}$ & $\begin{array}{l}3 \\
3\end{array}$ & $\begin{array}{l}3 \\
3\end{array}$ & $\begin{array}{l}3 \\
3\end{array}$ & \\
\hline 2 & $\begin{array}{l}\text { Pelaksanaan } \\
\text { A. pendahuluan } \\
\text { - Mengisi daftar hadir } \\
\text { - Menggali pengetahuan awal murid } \\
\text { - Memotivasi murid } \\
\text { - Menyampaikan tujuan pembelajaran. } \\
\text { B. kegiatan inti } \\
\text { a. mempresentasikan } \\
\text { - pendukung } \\
\text { Memberikan kesempatan bertanya } \\
\text { b. Mepada murid } \\
\text { - Menghargai kenderampilan kooperatif } \\
\text { - Mendengarkan dengan aktif } \\
\text { - Mempunyai keberanian dalam }\end{array}$ & $\begin{array}{l}3 \\
3 \\
4 \\
3\end{array}$ & $\begin{array}{l}3 \\
3 \\
4 \\
3\end{array}$ & $\begin{array}{l}3 \\
3 \\
4 \\
3\end{array}$ & 3,44 & Cukup baik \\
\hline
\end{tabular}




\begin{tabular}{|c|c|c|c|c|c|c|}
\hline & $\begin{array}{l}\text { bertanya } \\
\text { - Aktif dalam tugas } \\
\text { c. Mengawasi setiapa murid secara } \\
\text { bergantian } \\
\text { d. Memberi bantuan kepada murid } \\
\text { yang mendapat kesulitan } \\
\text { e. Memberi umpan balik atau } \\
\text { evaluasi } \\
\text { f. Membimbing murid dalam } \\
\text { mengerjakan LKS dengan benar } \\
\text { C. Penutup } \\
\text { - Memberikan refleksi } \\
\text { - Membimbing } \\
\text { menyimpulkan materi pelajaran }\end{array}$ & $\begin{array}{l}3 \\
3 \\
3 \\
4\end{array}$ & $\begin{array}{l}3 \\
3 \\
3 \\
4\end{array}$ & $\begin{array}{l}3 \\
3 \\
3 \\
4\end{array}$ & 3,5 & Cukup baik \\
\hline 3 & Materi pembelajaran & 4 & 4 & 4 & 4 & Baik \\
\hline 4 & Pengelolaan waktu & 3 & 3 & 3 & 3 & Cukup baik \\
\hline 5 & $\begin{array}{l}\text { Teknik bertanya } \\
\text { Suasana kelas } \\
\text { - Berpusat pada murid } \\
\text { - Murid antusia } \\
\text { - Guru antusias }\end{array}$ & $\begin{array}{l}3 \\
3 \\
4 \\
4\end{array}$ & $\begin{array}{l}3 \\
4 \\
4\end{array}$ & $\begin{array}{l}3 \\
4 \\
4\end{array}$ & 3,36 & Cukup baik \\
\hline & Jumlah & 75 & 75 & 75 & 23,45 & \\
\hline & Rata-rata nilai & 37,5 & 37,5 & 37,5 & 3,35 & Cukup baik \\
\hline
\end{tabular}

Keterangan skor

1 = tidak baik

$2=$ kurang baik

$\mathrm{P} 1$ = Pengamat pertama

$\mathrm{P} 2$ = Pengamata Kedua

$3=$ cukup baik

$\mathrm{X}=$ rata rata penilaian $\mathrm{P} 1$ dan $\mathrm{P} 2$

4 = baik

$\mathrm{Y}=$ rata-rata kategori tiap $\mathrm{KBM}$

Ketuntasan individu dan klasikal yang diperoleh dari hasil pre test dan post test siklus II

\section{Hasil belajar siklus II}

\section{Pertemuan ke 3}

\begin{tabular}{|l|l|l|l|l|}
\hline Tes & Tuntas & Tidak tuntas & $\begin{array}{l}\text { Jumlah } \\
\text { murid }\end{array}$ & $\begin{array}{l}\text { \% } \\
\text { Tuntas }\end{array}$ \\
\hline Pre Test & $\mathbf{2 2}$ & $\mathbf{1 0}$ & $\mathbf{3 2}$ & $\mathbf{6 9 \%}$ \\
\hline Post Test & $\mathbf{2 7}$ & $\mathbf{5}$ & $\mathbf{3 2}$ & $\mathbf{8 4 \%}$ \\
\hline
\end{tabular}

(sumber data pre test dan post test siklus II) 
Dari tabel di atas dapat dibuat grafik sebagai berikut:

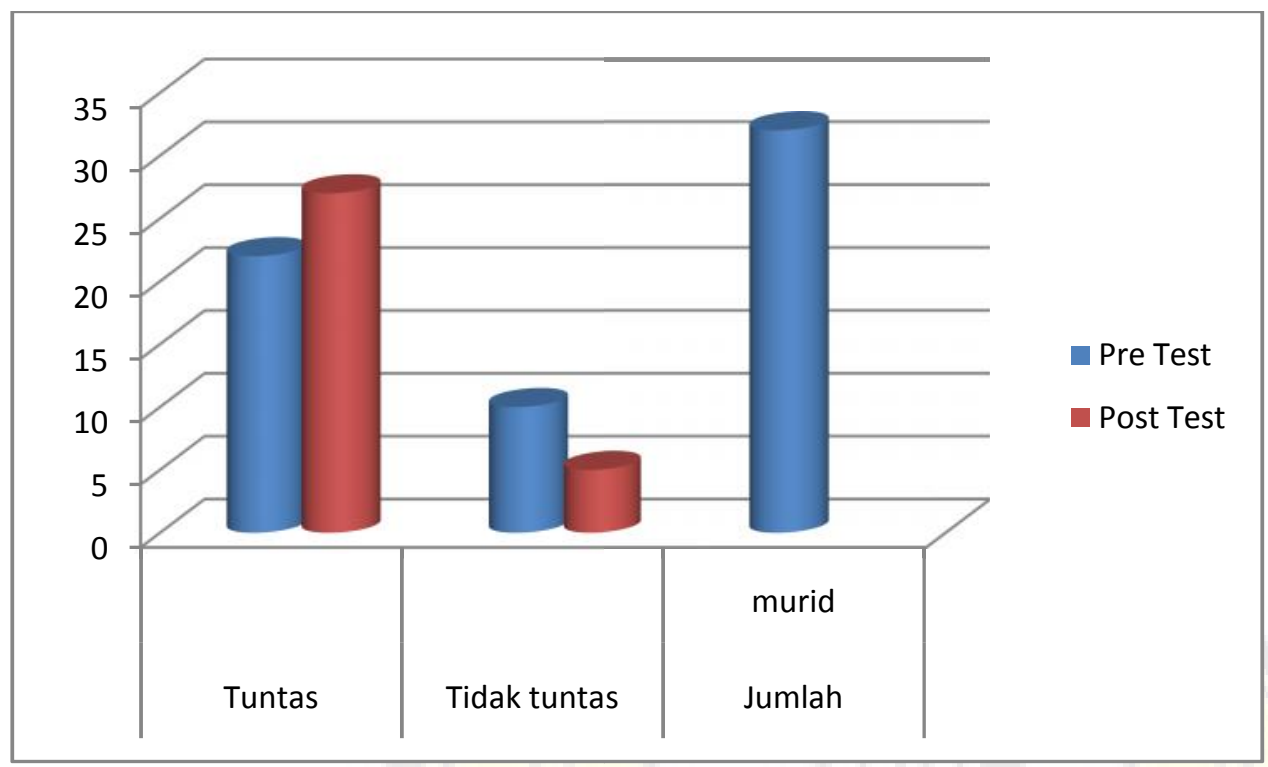

Berdasarkan tabel 8 pada pertemuan 3 ketuntasan secara individual dan klasikal melalui pretest yang tuntas ada 22 orang dengan nilai rata rata pretest adalah 66,87 dan pos test adalah 72,18 dan ketuntasan klasikal untuk pretest adalah $69 \%$ dan post test $84 \%$.

Nilai yang diperoleh murid pada proses pembelajaran siklus II (peretmuan 4)

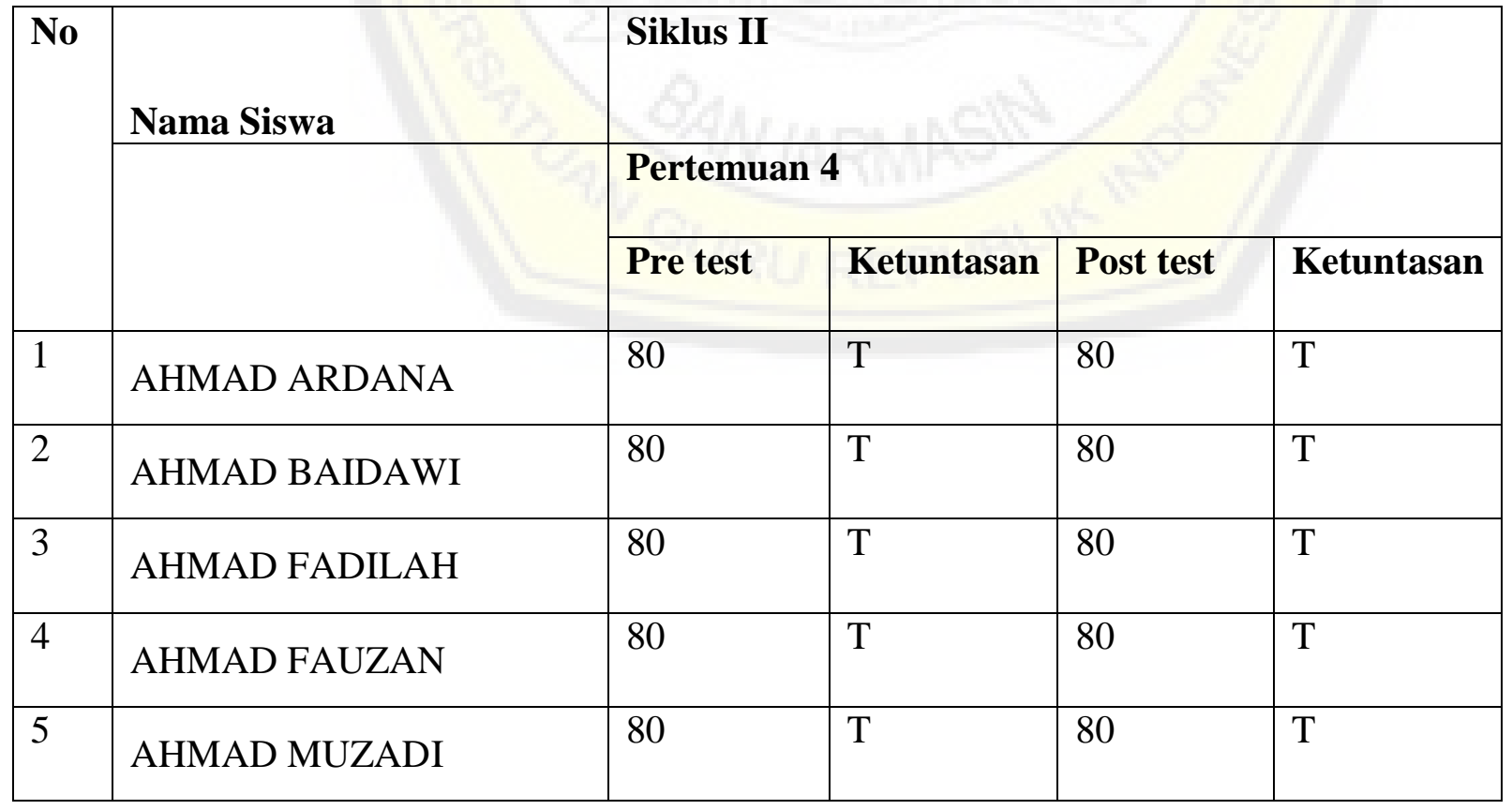




\begin{tabular}{|l|l|l|l|l|l|}
\hline 6 & AKHMAD FAHMI & 70 & $\mathrm{~T}$ & 80 & $\mathrm{~T}$ \\
\hline 7 & DEA SHAFIRA ADISTI & 70 & $\mathrm{~T}$ & 80 & $\mathrm{~T}$ \\
\hline 8 & DHEA SAPUTRI & 70 & $\mathrm{~T}$ & 80 & $\mathrm{~T}$ \\
\hline 9 & DINA RIZKA & 70 & $\mathrm{~T}$ & 80 & $\mathrm{~T}$ \\
\hline 10 & DINA SAFIRA & 70 & $\mathrm{~T}$ & 80 & $\mathrm{~T}$ \\
\hline 11 & HABIBAH SALWA & 70 & $\mathrm{~T}$ & 70 & $\mathrm{~T}$ \\
\hline 12 & $\begin{array}{l}\text { M. RISWANA } \\
\text { ANUGERAH }\end{array}$ & 70 & $\mathrm{~T}$ & 70 & $\mathrm{~T}$ \\
\hline 13 & M. RIZWAN FAZERI & 70 & $\mathrm{~T}$ & 70 & $\mathrm{~T}$ \\
\hline 14 & M. NOR ANNAS JAMIL & 70 & $\mathrm{~T}$ & 70 & $\mathrm{~T}$ \\
\hline 15 & MARSA ALIFIA & 70 & $\mathrm{~T}$ & 70 & $\mathrm{~T}$ \\
\hline 16 & $\begin{array}{l}\text { MUHAMMAD ALI } \\
\text { MUSTOFA }\end{array}$ & 80 & $\mathrm{~T}$ & 80 & $\mathrm{~T}$ \\
\hline 17 & MUHAMMAD FAHLEVI & 80 & $\mathrm{~T}$ & 80 & $\mathrm{~T}$ \\
\hline 18 & MUHAMMAD LUTHFI & 80 & $\mathrm{~T}$ & 80 & $\mathrm{~T}$ \\
\hline 19 & $\begin{array}{l}\text { MUHAMMAD RAIHAN } \\
\text { RIDHA }\end{array}$ & 80 & $\mathrm{~T}$ & 80 & $\mathrm{~T}$ \\
\hline 20 & $\begin{array}{l}\text { MUHAMMAD RIZKI } \\
\text { ANANDA }\end{array}$ & 80 & $\mathrm{~T}$ & 80 & $\mathrm{~T}$ \\
\hline 21 & MUHAMMAD SYAFIE & 70 & $\mathrm{~T}$ & 70 & $\mathrm{~T}$ \\
\hline 22 & MUNAWARAH & 70 & $\mathrm{~T}$ & 70 & $\mathrm{~T}$ \\
\hline 23 & MUTIA WAHIDAH & 70 & $\mathrm{~T}$ & 70 & $\mathrm{~T}$ \\
\hline 24 & MUTIARA QALBINA & 70 & $\mathrm{~T}$ & 70 & $\mathrm{~T}$ \\
\hline 25 & NAIMATUL HUDA & 70 & $\mathrm{~T}$ & 70 & $\mathrm{~T}$ \\
\hline 26 & NIA RAMADHANI & 80 & $\mathrm{~T}$ & 90 & $\mathrm{~T}$ \\
\hline 27 & NIDA SYAFIRA & 80 & 90 & $\mathrm{~T}$ \\
\hline & NUZILLA & & $\mathrm{T}$ & $\mathrm{T}$ \\
\hline & & & & & \\
\hline
\end{tabular}


Vol.3 No.2, 1 Oktober 2018

\begin{tabular}{|l|l|l|l|l|l|}
\hline 29 & NOOR FINA RAHMAH & 80 & T & 90 & T \\
\hline 30 & NURHIDAYAH & 80 & T & 90 & T \\
\hline 31 & RAUDATUL KHATIMAH & 80 & T & 90 & T \\
\hline 32 & RIZQA MAULIDA & 80 & T & 90 & T \\
\hline
\end{tabular}

\section{Keterangan}

$\mathrm{T}=$ Tuntas

$\mathrm{TT}=$ Tidak Tuntas

Ketuntasan individu dan klasikal yang diperoleh dari hasil pre test dan post test siklus II

\section{Hasil belajar siklus II}

\section{Pertemuan ke 4}

\begin{tabular}{|l|l|l|l|l|}
\hline Tes & Tuntas & Tidak tuntas & $\begin{array}{l}\text { Jumlah } \\
\text { murid }\end{array}$ & $\begin{array}{l}\text { \% } \\
\text { Tuntas }\end{array}$ \\
\hline Pre Test & 32 & $\mathbf{0}$ & $\mathbf{3 2}$ & $\mathbf{1 0 0} \%$ \\
\hline Post Test & $\mathbf{3 2}$ & $\mathbf{0}$ & $\mathbf{3 2}$ & $\mathbf{1 0 0} \%$ \\
\hline
\end{tabular}

(sumber data pre test dan post test siklus II)

Dari tabel di atas dapat dibuat grafik sebagai berikut:

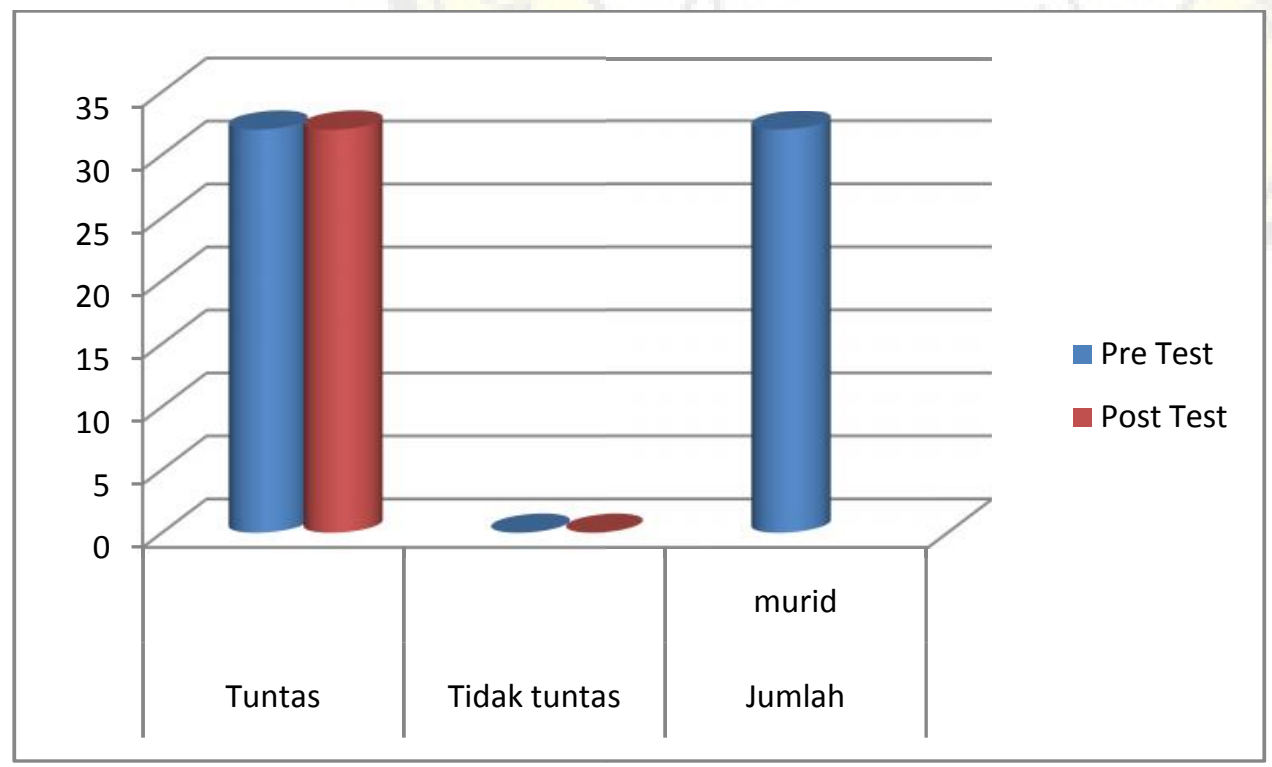


Berdasarkan Tabel 13 pada pertemuan 4 semua murid mencapai ketuntasan $100 \%$ dengan nilai rata rata pretest adalah 75,31 dan pos test adalah 79,06 .

Data Guru Dalam Mengelola Pembelajaran Siklus II Hasil Observasi Aktivitas Guru Dalam Mengelola Pembelajaran

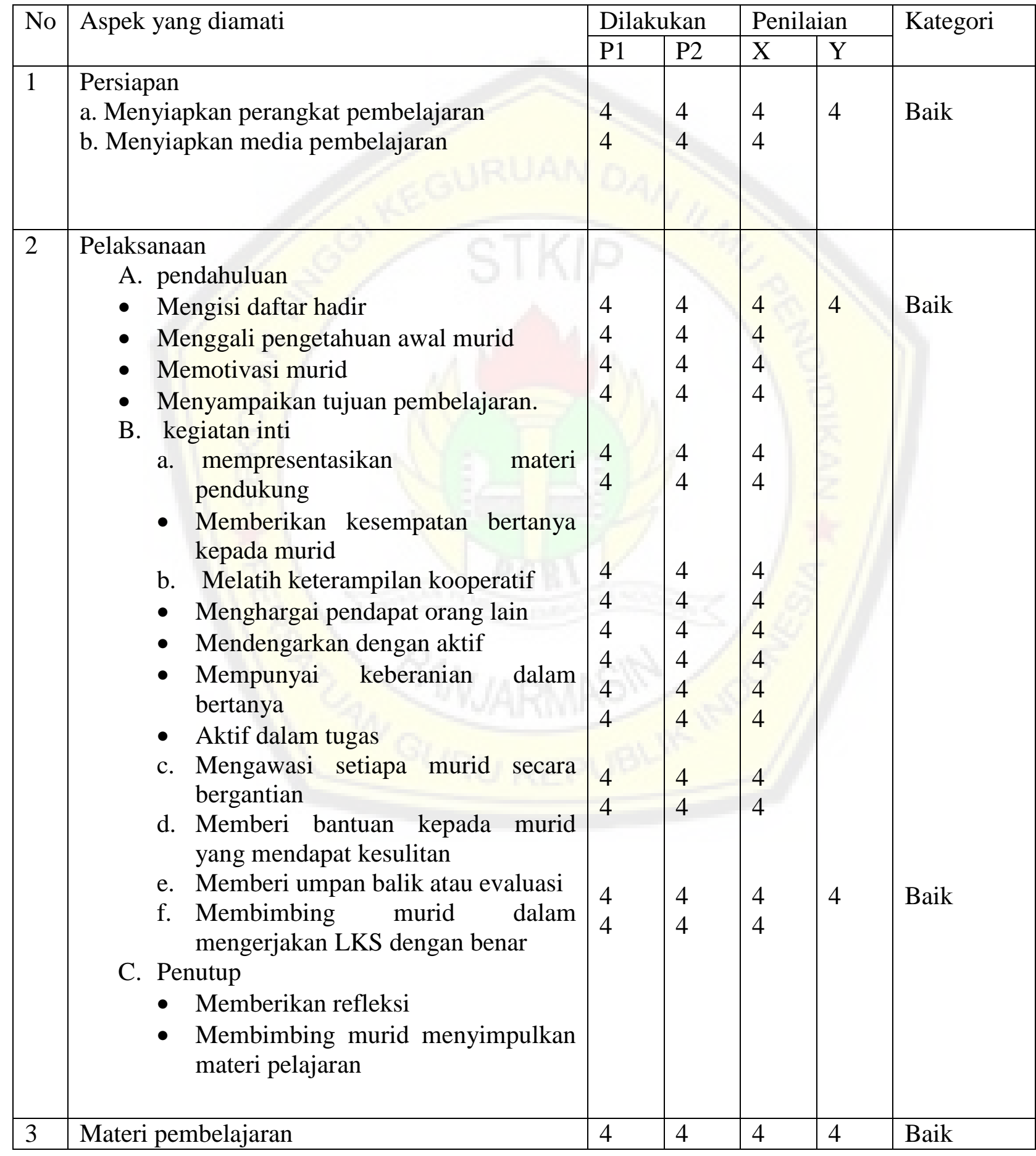




\begin{tabular}{|l|l|l|l|l|l|l|}
\hline 4 & Pengelolaan waktu & 4 & 4 & 4 & 4 & Baik \\
\hline 5 & Teknik bertanya & & & & & \\
& Suasana kelas & 4 & 4 & 4 & 4 & Baik \\
& $\bullet \quad$ Berpusat pada murid & 4 & 4 & 4 & & \\
& $\bullet$ Murid antusia & 4 & 4 & 4 & & \\
& $\bullet \quad$ Guru antusias & 88 & 88 & 88 & 28 & \\
\hline & Jumlah & 4,00 & 4,00 & 4,00 & 4,00 & Baik \\
\hline & Rata-rata nilai & & &
\end{tabular}

Keterangan skor

$1=$ tidak baik

$2=$ kurang baik

$\mathrm{P} 1$ = Pengamat pertama

$3=$ cukup baik

$\mathrm{P} 2$ = Pengamata Kedua

$4=$ baik

$\mathrm{X}=$ rata rata penilaian $\mathrm{P} 1$ dan $\mathrm{P} 2$

$\mathrm{Y}=$ rata-rata kategori tiap KBM

\section{Respons siswa terhadap kegiatan pembelajaran dengan metode pembelajaran Pemanfaatan}

\section{Judul-Judul Lagu}

\begin{tabular}{|c|c|c|c|c|c|}
\hline \multirow{3}{*}{ No } & \multirow{3}{*}{ Uraian } & \multicolumn{4}{|c|}{ Respons siswa } \\
\hline & & \multicolumn{2}{|c|}{ Ya } & \multicolumn{2}{|l|}{ Tidak } \\
\hline & & jumlah & $\%$ & Jumlah & $\%$ \\
\hline 1 & $\begin{array}{l}\text { Apakah anda merasa senang mengikuti pembelajaran } \\
\text { dengan model pembelajaran Pemenfaatan Judul-Judul } \\
\text { Lagu }\end{array}$ & 32 & $100 \%$ & 0 & $0 \%$ \\
\hline 2 & $\begin{array}{l}\text { Apakah pembelajaran dengan metode Pemenfaatan } \\
\text { Judul-Judul Lagu hal yang baru bagi anda. }\end{array}$ & 32 & $100 \%$ & 0 & $0 \%$ \\
\hline 3 & $\begin{array}{l}\text { Apakah pembelajaran dengan Pemenfaatan Judul- } \\
\text { Judul Lagu menjadikan anda termotivasi di dalam } \\
\text { menulis Puisi. }\end{array}$ & 32 & $100 \%$ & 0 & $0 \%$ \\
\hline 4 & $\begin{array}{l}\text { Menurut anda apakah senang belajar } \\
\text { menggunakan metode penggunaan } \\
\text { Menulis Puisi? }\end{array}$ & 32 & $100 \%$ & 0 & $0 \%$ \\
\hline 5 & $\begin{array}{l}\text { Apakah dengan penggunaan model pembelajaran } \\
\text { Pemanfaatan Judul Judul Lagu dapat menumbuhkan } \\
\text { rasa kebersamaan dan tanggug jawab dalam diri kamu? }\end{array}$ & 28 & $87 \%$ & 4 & $13 \%$ \\
\hline 6 & $\begin{array}{l}\text { Apaka metode yang digunakan guru membuat kamu } \\
\text { merasa mudah dalam memahami Puisi. }\end{array}$ & 30 & $94 \%$ & 2 & $6 \%$ \\
\hline 7 & $\begin{array}{l}\text { Apakah dengan menggunakan model pembelajaran } \\
\text { Pemanfaatan Judul Judul Lagu dapat menumbuhkan } \\
\text { kekompakan dalam menyelesaikan tugas yang } \\
\text { diberikan guru untuk memperoleh hasil yang } \\
\text { maksimal. }\end{array}$ & 31 & $97 \%$ & 1 & $3 \%$ \\
\hline 8 & $\begin{array}{l}\text { Apakah tugas yang diberikan kepada anda jelas dan } \\
\text { mudah dilaksanakan }\end{array}$ & 32 & $100 \%$ & 0 & $0 \%$ \\
\hline 9 & $\begin{array}{l}\text { Apakah anda merasa belajar menulis dan } \\
\text { mengembangkan judul judul lagu menjadi sebuah puisi } \\
\text { telah memudahkan untuk memahami pembelajaran }\end{array}$ & 32 & $100 \%$ & 0 & $0 \%$ \\
\hline
\end{tabular}




\begin{tabular}{|l|l|l|l|l|l|}
\hline 10 & $\begin{array}{l}\text { Apakah anda merasa lebih mudah mengerjakan tugas } \\
\text { setelah mengikuti proses belajar mengajar dengan } \\
\text { model Pemanfaatan Judul Judul Lagu }\end{array}$ & $100 \%$ & 0 & $0 \%$ \\
\hline
\end{tabular}

\section{Simpulan}

Berdasarkan hasil penelitian dan pembahasan dalam Penelitian Tindakan Kelas (PTK) Yang telah dilaksanakan, maka dapat ditarik kesimpulan sebagai berikut:

a) Pemanfaatan judul-judul lagu dapat meningkatkan kemampuan menulis puisi pada murid kelas VII MTsN 3 Banjarmasin. Hal ini dibuktikan bahwa nilai hasil belajar siswa rata-rata pada siklus I pertemuan pertama dan kedua masih rendah. Pada siklus II pertemuan ketiga dan keempat mengalami peningkatan, pada pertemuan ketiga dengan rata-rata pretest 72,18 dengan ketuntasan klasikal $84 \%$, dan pada pertemuan ke empat rata-rata postest 79,06 dengan ketuntasan klasikal 100\%. Dengan demikian apabila ditinjau dari indikator keberhasilan siswa sudah memenuhi dan penelitian ini dapat dikatakan berhasil.

b) Terjadi peningkatan aktivitas guru pada Siklus I ke Siklus I dengan nilai rata rata 4 dalam pembelajaran menulis puisi dengan kategori pencapaian nilai amat baik. Demikian juga aktivitas murid juga mengalami peningkatan. Dalam hal ini aktivitas murid pada pembelajaran menulis Puisi semakin meningkat pada setiap pertemuan.

c) Respons murid dalam pembelajaran menulis puisi menggunakan judul lagu lagu cukup baik.dengan total persentasi hampir $100 \%$.

\section{Saran}

Berdasarkan simpulan di atas, maka peneliti menyampaikan saran-saran sebagai berikut:

a) Bagi siswa, hendaknya selalu belajar dengan sunggug-sungguh serta melaksanakan tugas yang diberikan guru sehingga mampu meningkatkan prestasi belajar.

b) Bagi guru, diharapkan dalam kegiatan pembelajaran untuk memotivasi dan meningkatkan kemampuan belajar siswa selalu menggunakan media atau alat peraga.

c) Bagi Kepala Sekolah, seharusnya selalu memberikan pembinaan melalui supervisi kelas, sehingga proses kegiatan belajar mengajar guru selalu bisa terkontrol.

\section{DAFTAR RUJUKAN}

Arikunto, Suharsimi. 2010. Penelitian Tindakan. Yogyakarta: Aditya Media.

Arsyad, Azhar. 1995. Media Pembelajaran. Jakarta: Raja Grafindo Persada. 
Badudu, J. S dan Zakaria, Syofyan. 1991. Pandai Berbahasa Indonesia 3. Jakarta: Depatemen Pendidikan dan Kebudayaan.

Djamarah, Syaiful Bahri dan Zain, Aswan. 2010. Strategi Belajar Mengajar. Jakarta: Rineka Cipta.

Hamdani, Abdul Kodir. 2010. Strategi Belajar Mengajar. Bandung: CV Pusaka setia

Musaba, Zulkifli dan Siddik, Mohammad. 2011. Dasar-dasar Menulis. Malang: Tunggal Mandiri.

Munsyi, Alif Danya 2012. Jadi Penulis Siapa Takut. Bandung: Kaifa PT Mizan Pustaka

Sambodja, Asep 2007. Cara mudah menulis Puisi.Jakarta: Bukupop

Suparno dan Yunus, Muhammad. 2009. Keterampilan Dasar Menulis. Indonesia: Universitas Terbuka.

Sutikno, Sobry. 2013. Belajar dan pembelajaran. Lombok: Holistica.

Tarigan, Henry Guntur. 1980. Menulis Sebagai Suatu Keterampilan Berbahasa. Bandung: Angkasa Bandung. 